\title{
SUMBER RISIKO DAN MITIGASI RISIKO JAMUR MERANG (Volvariella volvaceae) DI KECAMATAN JATISARI KABUPATEN KARAWANG
}

\author{
SOURCES OF RISK AND RISK MITIGATION OF MERANG MUSHROOM \\ (Volvariella volvaceae) IN JATISARI DISTRICT, KARAWANG REGENCY
}

\author{
Siti Sarah Melani*, Lies Sulistyowati, Lucyana Trimo \\ Fakultas Pertanian Universitas Padjadjaran \\ *E-mail: sitisarahmelani23@gmail.com \\ (Diterima 13-07-2021; Disetujui 22-07-2021)
}

\begin{abstract}
ABSTRAK
Jamur merang merupakan salah satu komoditas sayuran unggulan di Kabupaten Karawang. Pertumbuhan konsumsi komoditas jamur merang ini selalu meningkat setiap tahunnya. Risiko merupakan peluang terjadinya suatu kejadian yang dapat diukur oleh pengambil keputusan.Tujuan dari penelitian ini adalah mengidentifikasi mitigasi dan pemetaan risiko yang terjadi pada usahatani jamur merang di Kecamatan Jatisari Kabupaten Karawang. Analisis data yang digunakan dengan deskriptif kuantitatif dan House of Risk (HOR). Lokasi penelitian ini di Kecamatan Jatisari Kabupaten Karawang yang merupakan kecamatan yang memiliki anggota kelompok taninya dengan usaha budidaya jamur merang paling tinggi. Data yang digunakan merupakan data primer dan data sekunder yang diperoleh dari dinas-dinas yang berkaitan dengan usahatani jamur merang Berdasarkan hasil penelitian sumber (agen) risiko dalam usahatani jamur merang yang terjadi dalam beberapa musim terakhir dan berpotensi untuk muncul kembali di kemudian hari, yaitu: (1) Kekurangan modal untuk berusahatani jamur merang, (2) Harga jual jamur merang berfluktuatif, (3) Harga jamur merang di tingkat tengkulak lebih rendah dari pada di tingkat pasar. Alternatif aksi mitigasi risiko yang dapat dilakukan petani antara lain: (1) Pemerintah membantu pemodalan usahatani jamur merang dan lembaga lainnya, (2) Mempermudah proses pencairan di perbankan melalui FGD dengan pihak lembaga keuangan, (3) Mengadakan pelatihan mengenai manajemen keuangan di usahatani.
\end{abstract}

Kata kunci: Jamur merang, sumber risiko, mitigasi risiko

\begin{abstract}
Mushroom is one of the leading vegetable commodities in Karawang Regency. The consumption growth of this mushroom commodity always increases every year. Risk is an opportunity for an event to occur that can be measured by decision makers. The purpose of this study is to identify mitigation and risk mapping that occurs in mushroom farming in Jatisari District, Karawang Regency. Data analysis used descriptive quantitative and House of Risk (HOR). The location of this study is in Jatisari District, Karawang Regency, that Jatisari District, Karawang Regency is a subdistrict where members of the farmer group have the highest mushroom cultivation business. The data used are primary data and secondary data obtained from agencies related to mushroom farming. Based on the results of the study, the sources (agents) of risk in mushroom farming that have occurred in the last few seasons and have the potential to reappear in the future, are: (1) Lack of capital for mushroom farming, (2) The selling price of edible mushroom fluctuates, (3) The price of edible mushroom at the middleman level is lower than the market level. Alternative risk mitigation actions that can be taken by farmers include: (1) The government helps capitalize on mushroom farming and other institutions, (2) Facilitates the disbursement process in banking through FGDs with financial institutions, (3) Conducts training on financial management in farming.
\end{abstract}

Keywords: Mushrooms, sources of risk, risk mitigation 


\section{PENDAHULUAN}

Jamur merupakan salah satu komoditas hortikultura sayuran yang mulai banyak diminati oleh masyarakat di Indonesia. Di Indonesia, jamur merang merupakan jamur yang paling banyak dibudidayakan hingga mencapai 55-60\% produksi nasional (http://www.hortikultura-bandung.com). Sebagian besar produksi jamur dipasarkan dalam bentuk segar terutama ke kota-kota besar (Pasaribu et al., 2002). Kendala yang dihadapi dalam pemasaran adalah jamur merang merupakan komoditas yang perishable atau sangat mudah rusak, sehingga tidak dapat bertahan lama bila disimpan pada suhu ruang. Produktivitas di Indonesia menunjukkan, dari tahun 2015 sampai tahun 2019 tingkat konsumsi di Indonesia akan jamur merang mengalami perkembangan.

Produksi jamur merang memiliki peluang yang baik di pasaran karena jumlah konsumsi penduduk di Indonesia dari tahun ke tahun mengalami perkembangan yang cukup fluktuatif. Produksi jamur merang mengalami peningkatan pada tahun 2015 hingga tahun 2016 mencapai 22\%. Produksi jamur merang mengalami penurunan dratis tahun 2018 dimana produksinya sebesar 31.052 ton atau tingkat persentase $16,12 \%$. Data di atas juga menunjukkan bahwa luas panen tidak begitu berpengaruh pada tingkat produksi jamur merang. Hal ini dapat dilihat dengan membandingkan data tahun 2015 dan 2019. Pada tahun 2015 jumlah luas panen jamur merang sebesar 536 hektar, hanya dapat menghasilkan produksi jamur merang sebesar 33.485 ton, sedangkan pada tahun 2016 dengan jumlah luas lahan sebesar 467 hektar dapat menghasilkan 40.914 ton.

Salah satu daerah yang menjadi sentra jamur merang di Indonesia adalah Jawa Barat. Menurut Direktorat Jenderal Hortikultura (2016), beberapa daerah yang menjadi sentra produksi sayuran di Jawa Barat antara lain Karawang, Bandung barat, Bogor, Subang, Cianjur. Sentra produksi penghasil jamur merang dengan tingkat produksi tertinggi jamur merang yaitu di Kabupaten Karawang. Lima komoditas yang banyak ditanam oleh petani di daerah tersebut adalah jamur merang, kacang panjang, ketimun, terung, cabai rawit. Namun, produktivitas sayuran pada daerah tersebut dari tahun 2015 sampai tahun 2019 mengalami fluktuasi. Adanya fluktuasi tersebut mengindikasikan adanya risiko produksi yang sering dihadapi petani. Jamur merang memberikan kontribusi terbesar 
terhadap produksi sayuran tahunan di Kabupaten Karawang (BPS, 2019). Untuk mengetahui data produktivitas sayuran pada beberapa daerah sentra produksi sayuran di Jawa Barat pada tahun 2015-2019.

Jamur merang merupakan salah satu komoditas sayuran unggulan di Kabupaten Karawang. Kegiatan pemasaran produk sayuran terkendala pada mutu produk sayuran yang terkadang sulit diterima oleh konsumen. Produk sayuran yang dijual terkadang ada yang sudah busuk, layu, dan tidak segar lagi. Hal ini disebabkan karena sayuran terlalu lama disimpan dan tidak dipacking dengan baik. Sayuran secara umum memiliki keriteria yaitu mudah busuk, tidak tahan disimpan lama, dan mudah rusak. Penjelasan singkat tentang usaha komoditi jamur merang tersebut dapat menggambarkan bahwa dalam usahatani jamur merang memiliki kendala yang lebih besar dibandingkan dengan usahatani komoditi yang lainnya. Kendala yang dimaksud adalah tingginya tingkat risiko yang dihadapi, baik yang terkait dengan risiko produksi maupun pemasarannya. Pertumbuhan konsumsi komoditas jamur merang ini selalu meningkat setiap tahunnya. Permintaan jamur merang per hari mencapai 4-10 ton, sedangkan pasokan hanya sekitar 4-7 ton (Dinas Pertanian Kabupaten Karawang, 2019). Menurut Dinas Pertanian (2019), produktivitas jamur merang teringgi di Kabupaten Karawang terdapat di Kecamatan Jatisari yang merupakan setra produksi di tingkat kabupaten dengan jumlah produksi tertinggi. Wilayah sentra dan produksi jamur merang di Kabupaten Karawang tahun 2019.

Dalam berbagai kegiatan usahatani di bidang pertanian sering terjadi situasi ekstrim, yaitu kejadian yang mengandung risiko (risk events) dan kejadian yang tidak pasti (uncertainty events). Risiko produksi pertanian lebih besar dibandingkan risiko non-pertanian, karena pertanian sangat dipengaruhi oleh alam seperti faktor cuaca, penggunaan bibit yang kurang baik, proses budidaya, serta faktor pengetahuan sumber daya manusia yang masih terbatas, hama dan penyakit dan perubahan cuaca (Kementan, 2019). Selain alam, risiko juga dapat ditimbulkan oleh kegiatan pemasaran. Risiko harga disebabkan karena harga pasar tidak dapat dikuasai petani. Fluktuasi harga lebih sering terjadi pada hasil-hasil pertanian. Besar kecilnya risiko yang dihadapi oleh petani akan berdampak pada tingkat produksi 


\section{SUMBER RISIKO DAN MITIGASI RISIKO JAMUR MERANG (Volvariella volvaceae) \\ DI KECAMATAN JATISARI KABUPATEN KARAWANG \\ Siti Sarah Melani, Lies Sulistyowati, Lucy Trimo}

dan pendapatan yang diperoleh petani.

Adanya risiko tersebut berdampak pada tingkat pendapatan petani. Semakin tinggi risiko yang dihadapi oleh petani, maka peluang mengalami kerugian semakin tinggi.

Risiko adalah peluang terjadinya kemungkinan merugi yang dapat diketahui terlebih dahulu. Ketidakpastian adalah sesuatu yang tidak bisa diramalkan sebelumnya, dan karenanya peluang terjadinya merugi belum diketahui sebelumnya. Sumber ketidakpastian yang penting di sektor pertanian adalah fluktuasi hasil produksi pertanian dan fluktuasi harga. Selain itu, ketidakpastian harga menyebabkan fluktuasi harga dimana keinginan pedagang memperoleh keuntungan besar dan rantai pemasaran yang panjang sehingga terjadi turun naiknya harga. Menurut Ekaningtias (2011), ada beberapa faktor yang mempengaruhi pendapatan dalam usahatani yaitu pertama produksi, besar kecilnya produksi akan sangat mempengaruhi terhadap pendapatan usahatani tersebut. Kedua kumbung, besar kecilnya kumbung juga sangat berpengaruh terhadap produksi pertanian dan pendapatan usahatani.
Berdasarkan usahatani jamur merang, pendapatan dari usahatani jamur merang di Kecamatan Jatisari Kabupaten Karawang, adapun kendala usahatani jamur merang yaitu rendahnya nilai pendapatan petani, keterbatasan lahan yang dimiliki petani dan posisi penawaran pada pihak petani yang kurang kuat menyebabkan rendahnya nilai keuntungan yang diperoleh petani. Fluktuasi harga lebih sering terjadi pada hasil-hasil pertanian. Besar kecilnya risiko yang dihadapi oleh petani akan berdampak pada tingkat produksi dan pendapatan yang diperoleh petani. Adanya risiko tersebut berdampak pada tingkat pendapatan petani. Semakin tinggi risiko yang dihadapi oleh petani, maka peluang mengalami kerugian semakin tinggi.

Berdasarkan uraian pendahulu, dapat disimpulkan bahwa jamur merang menghadapi risiko produksi yang ditandai dengan adanya variasi pada produktivitas jamur merang. Risiko produksi diduga disebabkan oleh penggunaan input produksi dan pengaruh lingkungan. Selain risiko produksi, diduga petani juga menghadapi keempat risiko lainnya, yaitu risiko produksi, risiko harga dan pasar, risiko manusia dan risiko finansial. Risiko akan 
berdampak pada pendapatan petani jamur merang. Oleh karena itu, perlu dilakukan perhitungan terhadap sumber-sumber risiko dan pendapatan petani. Upaya ini diharapkan dapat memberikan masukan bagi petani dalam memperbaiki dan meningkatkan peluang keberhasilan dalam usahatani jamur merang di Kecamatan Jatisari Kabupaten Karawang.

Berdasarkan latar belakang di atas maka tujuan yang ingin dicapai dalam penelitian ini yaitu: 1) Apa saja sumbersumber risiko yang dihadapi petani dalam usahatani jamur merang di Kecamatan Jatisari Kabupaten Karawang? 2) Bagaimana mitigasi dan pemetaan risiko jamur merang di Kecamatan Jatisari Kabupaten Karawang?

\section{METODE PENELITIAN}

Jenis penelitian yang digunakan adalah menggunakan desain penelitian mix method yaitu kombinasi metode kualitatif dan kuantitatif. Penelitian ini dilaksanakan di Kecamatan Jatisari Kabupaten Karawang. Pemilihan lokasi dilakukan secara sengaja (perposive).

Sumber data yang digunakan dalam penelitian ini adalah data primer dan data sekunder. Data diperoleh melalui wawancara terstruktur dan dokumentasi.
Pada penelitian ini, pengambilan sampel atau responden dilakukan dengan ketentuan jumlah sampel yang diambil dari keseluruhan anggota kelompok tani yang berada di Kecamatan Jatisari Kabupaten Karawang yaitu sebanyak 120 responden yang berusahatani jamur merang.

Menurut Sugiyono (2012), teknik purposive merupakan teknik penentuan sampel berdasarkan kriteria-kriteria atau pertimbangan tertentu. Menentukan sumber dengan teknik purposive ialah pengambilan sampel sumber data dengan pertimbangan tertentu, yaitu sumber data dianggap paling tahu tentang apa yang diharapkan sehingga mempermudah peneliti untuk menjelajahi objek atau situasi sosial yang sedang diteliti, rekomendasi dari informan awal yang mengetahui tentang keadaan dan kondisi usahatani, risiko, budidaya jamur merang di Kecamatan Jatisari Kabupaten Karawang.

Analisis data pada penelitian ini meliputi:

\section{Analisis Risiko Model House Of Risk (HOR)}

Metode analisis data yang digunakan dalam penelitian ini adalah metode House of Risk (HOR) yang merupakan salah satu analisis yang sering digunakan dalam manajemen risiko. 


\section{SUMBER RISIKO DAN MITIGASI RISIKO JAMUR MERANG (Volvariella volvaceae) \\ DI KECAMATAN JATISARI KABUPATEN KARAWANG \\ Siti Sarah Melani, Lies Sulistyowati, Lucy Trimo}

HOR merupakan sebuah framework yang dikembangkan dengan melakukan pengembangan metode FMEA (Failure Mode and Effect Analysis) dan metode QFD (Quality Function Deployment) diharapkan mampu mengendalikan agen risiko yang dianggap prioritas sehingga aksi mitigasi risiko dapat berjalan secara efektif (Pujawan, 2009).

Penggunaan pendekatan tersebut didasarkan pada alasan bahwa metode ini dapat digunakan untuk melakukan analisis penyebab potensial timbulnya suatu gangguan, probabilitas kemunculan serta cara penangannya (Nord dan Johansson dalam Pujawan et al, 2009). Menurut Pujawan (2009), penerapan HOR terdiri atas dua tahap, yaitu:

\section{a. House of Risk 1}

HOR fase 1 merupakan tahapan awal yang digunakan untuk mengidentifikasi kejadian risiko dan agen risiko yang berpotensi timbul sehingga hasil output dari HOR fase 1 ini yaitu pengelompokkan agen risiko ke dalam agen risiko prioritas sesuai dengan nilai Aggregate Risk Potential (ARP).

Perhitungan nilai indeks prioritas risiko/Aggregate Risk Potential (ARP) yang merupakan hasil dari kemungkinan munculnya agen/sumber risiko dan akibat agregat dari terjadinya risiko yang disebabkan oleh sumber risiko. Urutkan sumber risiko berdasarkan nilai ARPj, mulai dari nilai terbesar sampai nilai terkecil. Aggregate Risk Potentials dari risk agent dapat dihitung dengan cara:

$$
\operatorname{ARP} j=0 j \sum_{i} S i R i j \ldots
$$

Keterangan:

$$
\begin{aligned}
& \mathrm{ARPj}=\text { Agen Potensial Risiko Agregat } \\
& \mathrm{Oj}=\text { Peluang terjadinya risiko } \\
& \mathrm{Si} \quad=\text { Dampak kejadian risiko } \\
& \mathrm{Rij}=\text { Tingkat keterhubungan antara } \\
& \text { sumber risiko dengan kejadian risiko } \\
& \text { (korelasi) }
\end{aligned}
$$

\section{b. House of Risk 2}

House of Risk 2 ini digunakan untuk menentukan penanganan mana yang harus diselesaikan terlebih dahulu. Perusahaan harus memilih aksi penanganan yang ideal, artinya tingkat kesulitannya rendah jika dilakukan namun akan efektif untuk mengurangi kemungkinan terjadinya agen atau sumber risiko.

\section{Pemetaan Risiko}

Pengukuran risiko selanjutnya adalah pemetaan risiko. Manajemen akan mampu menilai suatu risiko dengan adanya pengelompokan terhadap risiko. Prinsip pemetaan merupakan penyusunan risiko berdasarkan kelompok-kelompok tertentu sehingga manajemen dapat 
mengidentifikasi karakter dari masingmasing risiko hingga menetapkan tindakan yang sesuai terhadap masingmasing risiko. Pemetaan risiko dapat dilakukan dengan menggunakan matriks frekuensi atau kemungkinan dan signifikansi (dampak) risiko. Teknik ini cukup sederhana karena tidak melibatkan kuantifikasi yang rurnit. Risiko dapat dikelompokkan pada dua dimensi, yaitu dimensi frekuensi dan dampak.

Peta risiko adalah suatu grafik yang menggambarkan kedudukan risiko Risiko yang ada pada kuadran ini memiliki dampak kecil pada pencapaian tujuan dan target petani. Sebelum melakukan pemetaan risiko, terlebih dahulu dianalisis status risiko untuk mengetahui prioritas sumber risiko yang harus ditangani terlebih dahulu. Status risiko diperoleh dari hasil perkalian probabilitas dan dampak. Probabilitas atau kemungkinan terjadinya risiko dapat dibagi menjadi dua bagian yaitu kemungkinan besar dan kemungkinan kecil. Pada penelitian ini, pengalaman selama menjalankan usaha budidaya jamur merang dan berdasarkan rata-rata pada setiap periode produksi. Penempatan risiko pada peta risiko didasarkan atas perkiraan posisinya berada dimana dari hasil perhitungan dampak. Hal yang dapat dilakukan untuk mengetahui posisi risiko tersebut adalah dengan melakukan perhitungan status risiko. Status risiko hanya menggambarkan urutan risiko dari kejadian yang paling berisiko sampai dengan yang paling tidak berisiko.

\section{HASIL DAN PEMBAHASAN}

Identifikasi terhadap sumbersumber risiko usahatani jamur merang yang terjadi di Kecamatan Jatisari berupa risiko produksi, risiko pasar dan harga, risiko finansial serta risiko manusia. Berdasarkan hasil survei dan wawancara dengan responden, diperoleh informasi beberapa risiko yang sering terjadi pada usahatani jamur merang di Kecamatan Jatisari. Penjelasan setiap risiko diuraikan sebagai berikut:

\section{Risiko Produksi}

Berdasarkan wawancara yang dilakukan dengan responden, diperoleh informasi bahwa risiko produksi pada usahatani jamur merang berasal dari pengadaan saprodi kurang, salah penanganan perawatan jamur merang, cuaca tidak dapat diprediksi, tanaman terserang hama dan penyakit, gagal panen, dan terlambat menanam.

Perubahan suhu merupakan salah satu sumber risiko produksi yang perlu 


\section{SUMBER RISIKO DAN MITIGASI RISIKO JAMUR MERANG (Volvariella volvaceae) \\ DI KECAMATAN JATISARI KABUPATEN KARAWANG \\ Siti Sarah Melani, Lies Sulistyowati, Lucy Trimo}

diperhatikan, karena jamur merang di Kecamatan Jatisari dapat tumbuh optimal di suhu yang cukup panas, paling tidak pembudidayaan harus disesuaikkan dengan kondisi habitat asli jamur merang di alam. Pada saat masuk musim kemarau perubahan suhu dapat berubah secara signifikan dan bisa mempengaruhi suhu ruangan terutama pada kumbung pemeliharaan, agar pertumbuhan tubuh buah jamur merang maksimal suhu kumbung harus dipertahankan sekitar 32 sampai 34 derajat celcius. Perubahan suhu yang tiba-tiba dapat mengganggu pertumbuhan jamur merang dan menyebabkan media tanam jika perubahan suhu terjadi petani jamur merang melakukan secara manual dengan menggunakan lampu atau drum untuk suhu didalam kumbung jamur merang tetap dengan suhu yang diinginkan maka pertumbuhan jamur merang tidak akan mungkin terjadi.

\section{Risiko Harga dan Pasar}

Untuk risiko harga pada usahatani jamur merang berasal dari fluktuasi harga log benih yang terjadi dikarenakan kesulitan mendapatkan log benih yang bagus. Salah satu sumber yang dapat menyebabkan fluktuasi harga adalah harga jamur merang konsumsi. Harga log benih jamur merang akan mengikuti perkembangan harga jamur merang konsumsi. Jika harga jamur merang konsumsi naik maka harga benih juga ikut naik, begitupun sebaliknya jika harga jamur merang konsumsi turun maka harga benih juga akan turun.

Batas bawah pada risiko harga jamur merang BS sebesar Rp28.000/kg atau jamur super sebesar Rp30.000/kg. Artinya harga terendah yang akan diterima petani pada saat terjadinya risiko harga sebesar Rp28.000/kg. Dimana hasil tersebut sudah melebihi jumlah batas bawah maka dapat dinyatakan usahatani jamur merang menguntungkan. Namun, apabila nilai batas bawah kebanyakan jamur BS maka usaha tersebut tidak menguntungkan.

\section{Risiko Manusia}

Risiko ini disebabkan oleh tingkah laku manusia dalam melakukan proses produksi. Sumberdaya manusia perlu diperhatikan untuk menghasilkan output optimal. Moral manusia dapat menimbulkan kerugian seperti adanya kelalaian sehingga menimbulkan kebakaran, pencurian dan rusaknya fasilitas produksi. berdasarkan hasil survei lapangan risiko yang sering terjadi di usahatani jamur merang di Kecamatan Jatisari yaitu kurangnya generasi petani yang membudidayakan jamur merang. 


\section{Risiko Finansial}

Risiko yang terjadi di usahatani jamur merang di Kecamatan Jatisari pada aspek risiko finansial yaitu masing minimnya modal yang diperoleh petani, sehingga petani lebih memilih meminjam modal ke rentenir, sumber modal seperti lembaga keuangan atau koperasi simpan pinjaman juga menjadi kendala di kalangan petani jamur merang. Berdasarkan hasil wawancara dengan beberapa informan dapat terindentifikasi 16 kejadian risiko yang terjadi dari risiko harga dan pasar, risiko manusia dan risiko finansial. Kejadian risiko yang sering terjadi selama beberpa musim taman terakhir dan berpeluang muncul dikemudian hari.

\section{Pemetaan House of Risk (HOR) Fase 1}

Hasil perhitungan risiko dan dampak dari masing-masing sumbersumber risiko produksi, pada usaha budidaya jamur merang telah dihitung dan dianalisis nilai-nilainya. Kemudian dapat dilakukan pemetaan risiko yaitu dengan maksud untuk mengukur risiko dan menghasilkan apa yang disebut dengan status risiko dan peta risiko. Status risiko adalah ukuran yang menunjukkan tingkatan risiko dari beberapa sumber risiko produksi yang telah teridentifikasi sebelumnya.
Pemetaan pada model ini dilakukan dengan memasukkan hasil pengukuran tingkat severity (keparahan) dari kejadian risiko dan occurance (kemunculan) dari agen risiko (Tabel 1) serta mengukur korelasinya. Nilai korelasi (tingkat korelasi) antara sumber risiko dan terjadinya risiko menggunakan skala 0,1,3,9. Skala 0 jika tidak ada korelasi, 1 jika korelasi rendah, korelasi sedang menggunakan skala 3 dan skala 9 menunjukkan korelasi tinggi. Tujuan dari pemetaan ini adalah mencari nilai ARP.

Nilai ARP didapatkan dari hasil perkalian antara nilai severity, nilai occurance dan nilai korelasi dari kejadian risiko dan agen risiko. Perhitungan nilai ARP bertujuan untuk menentukan tingkat prioritas dalam penanganan suatu agen risiko. Agen risiko tersebut kemudian akan diurutkan berdasarkan nilai ARP tertinggi hingga terendah. Melalui hasil analisis risiko diperoleh nilai ARP yang merupakan hasil dari output HOR fase 1.

\section{Perencanaa Aksi Mitigasi Risiko}

Sumber (agen) risiko ini kemudian akan dimasukkan ke dalam model HOR Fase 2 untuk perancangan aksi mitigasi. Aksi mitigasi yang dimaksud adalah tindakan (action) untuk mengurangi dampak dari suatu agen risiko sebelum risiko itu terjadi. Alternatif aksi mitigasi 


\section{SUMBER RISIKO DAN MITIGASI RISIKO JAMUR MERANG (Volvariella volvaceae) \\ DI KECAMATAN JATISARI KABUPATEN KARAWANG \\ Siti Sarah Melani, Lies Sulistyowati, Lucy Trimo}

diperoleh dari diskusi dengan beberapa ketua, anggota kelompok tani, petani, penyuluh dan Dinas Pertanian. Fokus perancangan aksi mitigasi ini berdasarkan dari sumber (agen) risiko terpilih (Tabel 1). Berdasarkan risiko tersebut maka terbentuklah delapan kriteria berserta alternatif aksi mitigasi yang akan digunakan untuk meminimalisasi kerugian yang terjadi akibat dari risiko yang muncul pada risiko akan diolah dengan menggunakan metode House of Risk Fase 2 (Kriteria dan alternatif aksi mitigasi risiko pada usahatani jamur merang). Pembobotan kriteria dilakukan untuk mengetahui kriteria yang menjadi prioritas. Menurut Nobar et al (2011), pembobotan dilakukan dengan melakukan perbandingan berpasangan antara komponen sumber agen risiko dan aksi mitigasi kemudian mengevaluasinya dengan menggunakan sehingga bobot kriteria didapatkan. Berdasarkan perhitungan diagram pareto dapat dilihat pada Tabel 1. Risiko tertinggi pada risiko usahatani jamur merang yaitu meminjam modal sebesar 79,200\% dengan komulatif nilai ARP yang dapat menimbulkan risiko lainnya, sehingga perlu dilakukan opsi aksi mitigasi risiko dari agen risiko terpilih pada Tabel 1.

\begin{tabular}{|c|c|c|c|}
\hline \multicolumn{2}{|c|}{$\begin{array}{c}\text { Sumber/ Agen } \\
\text { Risiko (Aj) }\end{array}$} & \multicolumn{2}{|c|}{$\begin{array}{c}\text { Aksi Mitigasi/ Preventive } \\
\text { Action (Pak) }\end{array}$} \\
\hline $\begin{array}{l}\text { Kekurangan } \\
\text { modal untuk } \\
\text { berusahatani } \\
\text { jamur merang }\end{array}$ & A8 & $\begin{array}{l}\text { Pemerintah } \\
\text { membantu } \\
\text { pemodalan } \\
\text { usahatani jamur } \\
\text { merang dan } \\
\text { lembaga lainnya }\end{array}$ & PA1 \\
\hline $\begin{array}{l}\text { Harga jual } \\
\text { jamur merang } \\
\text { berfluktuatif }\end{array}$ & A2 & $\begin{array}{l}\text { Perlunya } \\
\text { pemantauan harga } \\
\text { dipasar }\end{array}$ & PA2 \\
\hline $\begin{array}{l}\text { Harga jamur } \\
\text { merang di } \\
\text { tingkat } \\
\text { tengkulak } \\
\text { lebih rendah } \\
\text { dari pada di } \\
\text { tingkat pasar }\end{array}$ & A 3 & $\begin{array}{l}\text { Melakukan } \\
\text { sosialisasi kepada } \\
\text { tengkulak agar } \\
\text { harga dapat } \\
\text { ditingkatkan }\end{array}$ & PA3 \\
\hline $\begin{array}{l}\text { Pengeluaran } \\
\text { untuk } \\
\text { mencukupi } \\
\text { kebutuhan } \\
\text { petani tinggi }\end{array}$ & A9 & $\begin{array}{l}\text { Mengadakan } \\
\text { pelatihan mengenai } \\
\text { manajemen } \\
\text { keuangan di } \\
\text { usahatani } \\
\end{array}$ & PA4 \\
\hline $\begin{array}{l}\text { Penjualan } \\
\text { jamur merang } \\
\text { yang kurang } \\
\text { lancar }\end{array}$ & A4 & $\begin{array}{l}\text { Mendata konsumen } \\
\text { tetap baik secara } \\
\text { kecil maupun } \\
\text { partai besar }\end{array}$ & PA5 \\
\hline $\begin{array}{l}\text { Pinjaman bank } \\
\text { lama cair }\end{array}$ & A11 & $\begin{array}{l}\text { Mempermudah } \\
\text { proses pencaiaran } \\
\text { di perbankan } \\
\text { melalui FDG } \\
\text { dengan pihak } \\
\text { lembaga keuangan }\end{array}$ & PA6 \\
\hline $\begin{array}{l}\text { Bunga bank } \\
\text { tinggi }\end{array}$ & A12 & $\begin{array}{l}\text { Menentukan } \\
\text { kebijakan bunga } \\
\text { pinjaman terhadap } \\
\text { pinjaman untuk } \\
\text { usahatani }\end{array}$ & PA7 \\
\hline $\begin{array}{l}\text { Tidak ada } \\
\text { lembaga } \\
\text { keuangan } \\
\text { untuk } \\
\text { meminjam } \\
\text { modal } \\
\end{array}$ & A10 & $\begin{array}{l}\text { Bersosialisasi } \\
\text { dengan pihak } \\
\text { lembaga keuangan } \\
\text { agar membuka } \\
\text { agen disetiap desa- } \\
\text { desa }\end{array}$ & PA8 \\
\hline
\end{tabular}

Penelitian sumber agen risiko yang menjadi prioritas berjumlah delapan kriteria, yaitu kekurangan modal untuk berusahatani jamur merang, harga jual jamur merang berfluktuatif, harga jamur merang di tingkat tengkulak lebih rendah 
dari pada di tingkat pasar, pengeluaran untuk mencukupi kebutuhan petani tinggi, penjualan jamur merang yang kurang lancar, pinjaman bank lama cair, bunga bank tinggi, tidak ada lembaga keuangan untuk meminjam modal. Kriteria tersebut dipilih dalam penelitian sesuai dengan kondisi dilapangan karena merupakan aspek penting yang dapat menentukan analisis mitigasi risiko yang dilakukan usahatani jamur merang.

\section{Pemetaan House of Risk (HOR) Fase 2}

Pemetaan aksi mitigasi ini dilakukan dengan cara melakukan pemetaan opsi aksi mitigasi (Pak) dengan agen risiko (Aj) terpilih. Tujuan pemetaan ini adalah untuk melihat pengaruh aksi mitigasi terhadap agen risiko. Tetapi dampak yang diakibatkan oleh agen risiko juga harus tetap diperhatikan, walaupun nilai yang ditampilkan masih di bawah nilai dari nilai dampak dari risiko pada jamur merang. Hasil dari perhitungan ini selanjutnya akan dikombinasikan dengan hasil dari aksi mitigasi (Pak) dengan agen risiko (Aj) terpilih dari masing-masing sumber risiko produksi untuk menggambarkan bagaimana status dan prioritas masing-masing sumber risiko produksi dan posisinya pada suatu peta risiko.
Peta risiko adalah gambaran tentang posisi risiko pada suatu peta dari penempatan posisi risiko dilakukan berdasarkan hasil perhitungan teridentifikasi suatu kejadian risiko yang telah dilakukan sebelumnya. Pemetaan aksi mitigasi terdiri beberapa langkah, yaitu:

1. Mengukur nilai korelasi antara aksi mitigasi dan agen risiko terpilih.

2. Mengukur derajat kesulitan (Dk) untuk mengetahui derajat kesulitan dari penerapan aksi mitigasi. Skala nilai dalam derajat kesulitan yaitu:

- 3 : Aksi mitigasi mudah untuk diterapkan.

- 4 : Aksi mitigasi agak sulit untuk diterapkan.

- 5 : Aksi mitigasi sulit untuk diterapkan.

3. Mengukur total keefektifan (total effectiveness) dengan mengalikan nilai korelasi antara agen risiko dengan aksi preventif. Perhitungan total keefektifan bertujuan menilai keefektifan dari aksi mitigasi.

\section{KESIMPULAN DAN SARAN}

\section{Kesimpulan}

Berdasarkan hasil penelitian dapat disimpulkan bahwa: 


\section{SUMBER RISIKO DAN MITIGASI RISIKO JAMUR MERANG (Volvariella volvaceae) \\ DI KECAMATAN JATISARI KABUPATEN KARAWANG \\ Siti Sarah Melani, Lies Sulistyowati, Lucy Trimo}

1. Sumber (agen) risiko dalam usahatani jamur merang yang terjadi dalam beberapa musim terakhir dan berpotensi untuk muncul kembali di kemudian hari, yaitu: (1) Kekurangan modal untuk berusahatani jamur merang, (2) Harga jual jamur merang berfluktuatif, (3) Harga jamur merang ditingkat tengkulak lebih rendah dari pada ditingkat pasar, (4) Pengeluaran untuk mencukupi kebutuhan petani tinggi, (5) Penjualan jamur merang yang kurang lancar, (6) Pinjaman bank lama cair, (7) Bunga bank tinggi, dan (8) Tidak ada lembaga keuangan untuk meminjam modal.

2. Alternatif aksi mitigasi risiko yang dapat dilakukan petani antara lain: (1) Pemerintah membantu pemodalan usahatani jamur merang dan lembaga lainnya, (2) Mempermudah proses pencaiaran di perbankan melalui FGD dengan pihak lembaga keuangan, (3) Mengadakan pelatihan mengenai manajemen keuangan di usahatani, (4) Perlunya pemantauan harga di pasar, (5) Bersosialisasi dengan pihak lembaga keuangan agar membuka agen disetiap desa-desa,

Menentukan kebijakan bunga pinjaman terhadap pinjaman untuk usahatani, (7) Mendata konsumen tetap baik secara kecil maupun partai besar, dan (8) Melakukan sosialisasi kepada tengkulak agar harga dapat ditingkatkan

\section{Saran}

Berdasarkan kesimpulan di atas. maka saran yang dapat saya sampaikan adalah:

1. Berdasarkan hasil penelitian menunjukkan bahwa petani masih mengalami kesulitan dalam permodalan usahataninya, diharapkan sebagai pihak menyedia program bantuan modal kepada petani jamur merang.

2. Bagi pemerintah, memberikan bantuan modal, sehingga petani jamur merang dapat meningkatkan hasil produksi serta meningkatkan kesejahteraan.

\section{DAFTAR PUSTAKA}

Alijoyo, A. 2006. Enterprise Risk Management. Jakarta: PT. Ray Indonesia

Alfiani F, Mustika A. H, Wiwin Hartanto, W. 2018. Pengaruh Kuantitas Produk dan Harga Jual Terhadap Pendapatan Usahatani Jamur Merang (Studi kasus Pada Kelompok Tani Paguyuban Kaola Mandiri Di Desa Rambipuji Kecamatan Rambipuji Kabupaten Jember). 
Arikunto, S., 1992. Prosedur Penelitian: Suatu Pendekatan Praktik. Rineka Cipta

Deva, ZS. 2012. Manajemen Risiko Produksi Jamur Tiram Putih Pada Unit Usaha Milik Bapak Sukamto Di Desa Cipayung Kecamatan Megamendung Kabupaten Bogor. Fakultas Ekonomi dan Manajemen Institut Pertanian Bogor (ITB) Bogor

FAOStat. 2015. FAO Statistical Pocketbook World Food and Agriculture. Food and Agriculture Organization of The United Nations: FAO

Firas, Farisah. 2013. Analisi Risiko Produksi Dan Faktor-Faktor Yang Mempengaruhi Produksi Paprika Indonesia. Skripsi. IPB, Bogor.

Gunadi, Gunadi, N, Everaarts, A, Adiyoga, W, Moekasan, T, Muharam, A \& Subhan. 2006. 'Constraints and potential of sweet pepper cultivation in plastic houses in Indonesia', Acta Horticulturae, vol. 761, pp. 305-311.

Harwood, J, Richard Heifner, Keith H, Coble, Janet Perry, and Agapi Somwaru. 1999. Managing Risk in Farming Concepts, Researh and Analysis. Washington DC: Economic Research Service, USDA Kusno, K. Tarigan, J, F. 2017. Analisis Penyebab Risiko Produksi Jamur Shiitake (Lentinus edodes) di PT. Inti Jamur Raya, Desa Cikole, Kecamatan Lembang Kabupaten Bandung Barat. Jurnal Agribisnis dan Sosial Ekonomi Pertanian. Fakultas Pertanian, Universitas Padjadjaran.

Kountur, R. 2008. Manajemen Risiko Operasional Perusahaan. Jakarta: Pendidikan Pembinaan Manajemen

Kountur, R. 2008. Mudah Memahami Risiko Perusahaan. Jakarta: Pendidikan Pembinaan Manajemen
Lutuharheri, 2003. Production Cost Analysis of White Oyster Mushroom Cultivation in Bogor Region. Bogor. Bogor Agricultural University

Mayangsari, D. F., Adianto, H., \& Yuniati, Y. 2015. Usulan Pengendalian Kualitas Produk Isolator Dengan Metode Failure Mode And Effect Analysis (FMEA) dan Fault Tree Analysis (FTA). Jurnal Online Institut Teknologi Nasional, 81-91

Nobar, M.N, Steak, M dan Tafti, A.F. 2011. Selecting Supplier of 2nd Layer Suppliers by Utilizing FANP Procedure. International Journal of Business and Management. 6 (2)

Ookalkar, A., Joshi, A. G., \& Ookalkar, S. D. 2009. Quality Improvement in Haemodialysis Process using FMEA. International Journal of Quality \& Reliability Management, 817-830

Pasaribu, T., D.R. Permana, dan E.R. Alda. 2002. Aneka Jamur Unggulan yang menembus Pasar. Grasindo. Jakarta

Pujawan, I. and Geraldin, L.H., 2009. House of risk: a model for proactive supply chain risk management. Business Process Management Journal, 15(6), pp.953-967

Pujiharto. 2011. Agribisnis Sayuran Dataran Tinggi di Kabupaten Banjarnegara. Laporan Survey Awal Penelitian untuk Disertasi. Tidak dipublikasikan. Program Doktor Eonomi Pertanian Universitas Gadjah Mada, Yogyakarta

Robinson, L. J., \& Barry, P. J. 1987. The Competitive Firm's Response to Risk. London: Macmillan Publisher.

Roy, A., Prasad, P., \& Gupta, N. 2014. "Volvariella volvacea: A 


\section{SUMBER RISIKO DAN MITIGASI RISIKO JAMUR MERANG (Volvariella volvaceae) \\ DI KECAMATAN JATISARI KABUPATEN KARAWANG \\ Siti Sarah Melani, Lies Sulistyowati, Lucy Trimo}

Macrofungus Having Nutritional and Health Potential". Asian Journal. Vol:4. Num:2. Page:110113

Sadnyana, I M. 1999. Pengaruh Jenis Media dan Ketebalan Media terhadap Hasil Jamur Merang (Volvariella volvaceae). Skripsi. Fakultas Pertanian Universitas Udayana. Denpasar. 46 hal

Saputra, AS. Hani, ES. Suciati, LP. 2018. Risk Management Of Oyster Mushroom Agribusiness In Jember District. Agribusiness Study Program, Faculty Of Agriculture, University of Jember.

Simon Subagio. 2020. Hubungan Antara Jiwa Kewirausahaan dan Manajemen Agribisnis Terhadap Keberhasilan Usaha Jamur Tiram Di Daerah Pacet Kabupaten Mojokerto Jawa Timur. Tesis. Fakultas Pertanian Program Magister Pertanian Universitas Wijaya Kusuma Surabaya
Soekartawi. 1986. Ilmu usahatani dan Penelitian Untuk Pengembangan Petani Kecil. Universitas Indonesia. Jakarta.

Souza, R. V., \& Carpinetti, L. C. 2014. A FMEA based approach to prioritize waste reductionin lean implementation. International Journal of Quality \& reliability Management, 346-366.

Yunita. 2011. Strategi Peningkatan Kapasitas Petani Padi Sawah Lebak Menuju Ketahanan Pagan Rumah Tangga di Kabupaten Ogan Ilir dan Ogan Kemering Ilir Provinsi Sumatera Selatan. (Disertasi). Sekolah Pascasarjana Institut Pertanian Bogor. Bogor 